\title{
LA-UR-83- 1223
}

$\cdot \frac{1}{5^{-8}} \cdot 8^{3} B$

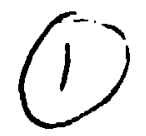

$$
\text { CONF-830425--14 }
$$

\section{DISCLAIMER}

\begin{abstract}
Thu roport we prepared as an eccount of work aponeored by an acency of the Uatied Stente Govornment. Neither the Unitud States Cowernment nor any agency thorwor, nor any of thedr

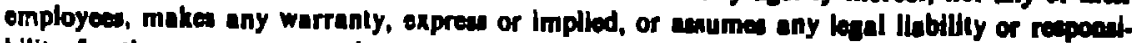
bility for the eccuracy, completeneas, or usefulnese of any information, apparatus, produch, or proceses disctosed, or reprosents that its use would not infinge privately owned righte. Refer.

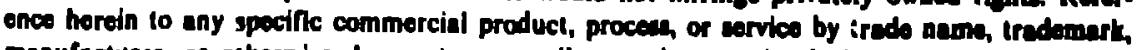

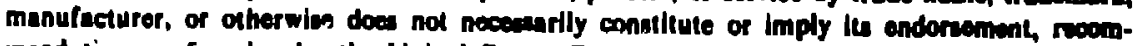
mendation, of fevoring by the United Siules Government or any apency thareof. The vom and opinions of authorn expresed herein do not necosarily utule or reflect thow of the Untiod Situte Government or any agoncy thereof.
\end{abstract}

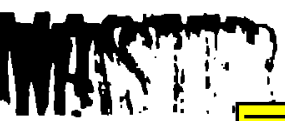

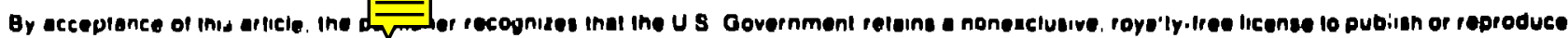
Ihe published lurm of inis conlribution, of to allow olhers 10 do 10 . for US Government Durposes 
Resonant wultiphoton ionization for the detection of technetiun

N. S. Nogar, R. K. Sander and S. W. Downey

Chemietry Diviaion

C. M. Miller

I eotope and Nuclear Chemletry Division

University of California, Loa ..lamon National Laporatory

P. O. Box 166j, Los Alamos, New Mexico 87545

\section{Introductien}

The occurrence of isobaric (same mase) interferences presenti a peraistent problem to the precise experimental determination of isotope ratios. The problar is particularly acuto when larga laotope ratios nust be measured, and in the determination of extrenely amall ampies, where counting statistice will make subtraction of a background algnal rather inaccurate. While there exigt classical technigues for reducting background interferences, the application of resonance fonization muse epectrometry (RIMs) currently eeme moet likely to provide an option colution to this probiam.-s We present hers a preliminary report on the application of RIMS to the selective detection of technetiun.

Technetiun is an extremely rare element exhibiting no etable ieotopes, it 1s nearly undetectable in normal crustal samples. Because of ite ocarcity it is particularly useful a a tracer in hydrologic and geologic sudies. Another potential application results from the fact that technetium can be used a en indicator for the pasage of solar neutrinos. It has been proposed to measure technetium iaotope ration in molybdenite ore in order to gain a meaure of the integrated boron-8 colar neutrino flux averaged over the past averal mililon yeara. Since the technetium is to be extiacted from molybdenite ore, 1 t is anticipated that lobaric interferences from molybdenum may present a ariou problem for the determis:itos of technetium isotope ratios. The application of Rims to this probler le clearly indicated. Our immediate goal are twofold: to determine optimun wavislengthe for the relective ionization of $T C$, and to atimate the ultimate sonaitivity obtainable for RIMS detection of TC in raal amples.

\section{Experimental}

The cxperimente were carried out uaing themal aton wource, pulaed laser, and tineof-flight maes opectrometer, as how in Fig. I Light pulses were genereted by frequeney doublins (Inrad Autotracker) the output of Nd+J;YAG (Quante Ray DCR 14) pumped dye laeer (Quanta Ray PDL) operated with Exciton DCy dye. Output conajeted of sio-ne pulea ranging in energy frol $0.2-2.5 \mathrm{~mJ}$, et $10 \mathrm{kz}$. The $1-\mathrm{cm}$ diameter pules were directed, without focuing, into the cource region of i-n time-of-filght mesepectrometer. io ionizetion took place in a contant field (7 V/Cw) region surround by a L.N, coojed cryotrap. The lone were eccolerated in two tege to $225 \mathrm{v}$ for flight through the drift tube. Ion flight tibes vere typically 35 pa. Ione vere detectod with a chennel edectron multiplier biased at $-2500 \mathrm{~V}$. The agnal was pzeaplified (PARC 1i5) and paseed to a gated integrator (PARC $164 / 162$ ) and $x-y$ recordar. A gate width of $-4, y e$ and a riae conetant of 1 vere routinaly uned. The gase rewolution of the yatem vae $-3-4$ anu.

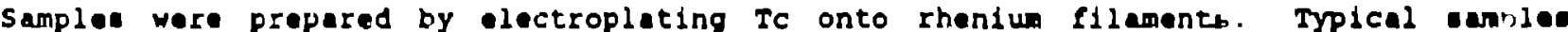

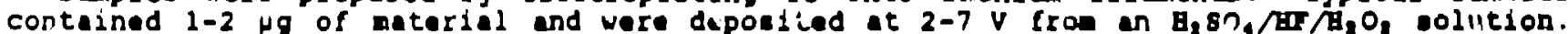
The lectrodeposition proces promotes the production of atonic technetiun and inhibite the fcrmation of nolecular epecies. Technetiun atons ware volatined in the enurce region of the masa spectroneter by reaitiveiy heating the Re fllanente. Thee filanente typlcally produced tible Tc eignale for 6-8 houre at a current of $-3 A\left(1300^{\circ} \mathrm{C}\right)$.

\section{Reaulte and pilecusetion}

Technetiun lons were generated vie almple $1+1$ photolonisotion echene utllising two photone of the eane frequency and real intermediete tate. We exanined only the epectral region for which th we of the photon energies vas near $(\sim 0.2$ v) the Te lonigation lialt $\left(58730 \mathrm{~cm}^{-1}, 7.28 \mathrm{al}\right)$. Thi wa dune for two reasonel firet, the probability of berkaroind lonization tonde to incraese with incieasing photon energy, and eecond, the trequency region fuet to the $h i g l i$ energy ide of $58730 / 2 \mathrm{ca}^{-1}$ is e parciculerly levorable region for the generation of tunable radation. rigures 2 and 3 diplay joilention eignal as runetion of excltation wavelength over the epectral range where phetolonization was observad. The one photon abeortion resonences yenereted lonlection rignale et the warelengthe ehown.

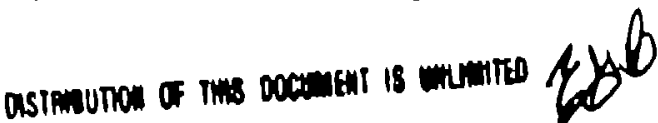




\section{TIME-OF-FLIGHT MASS SPECTROMETER}

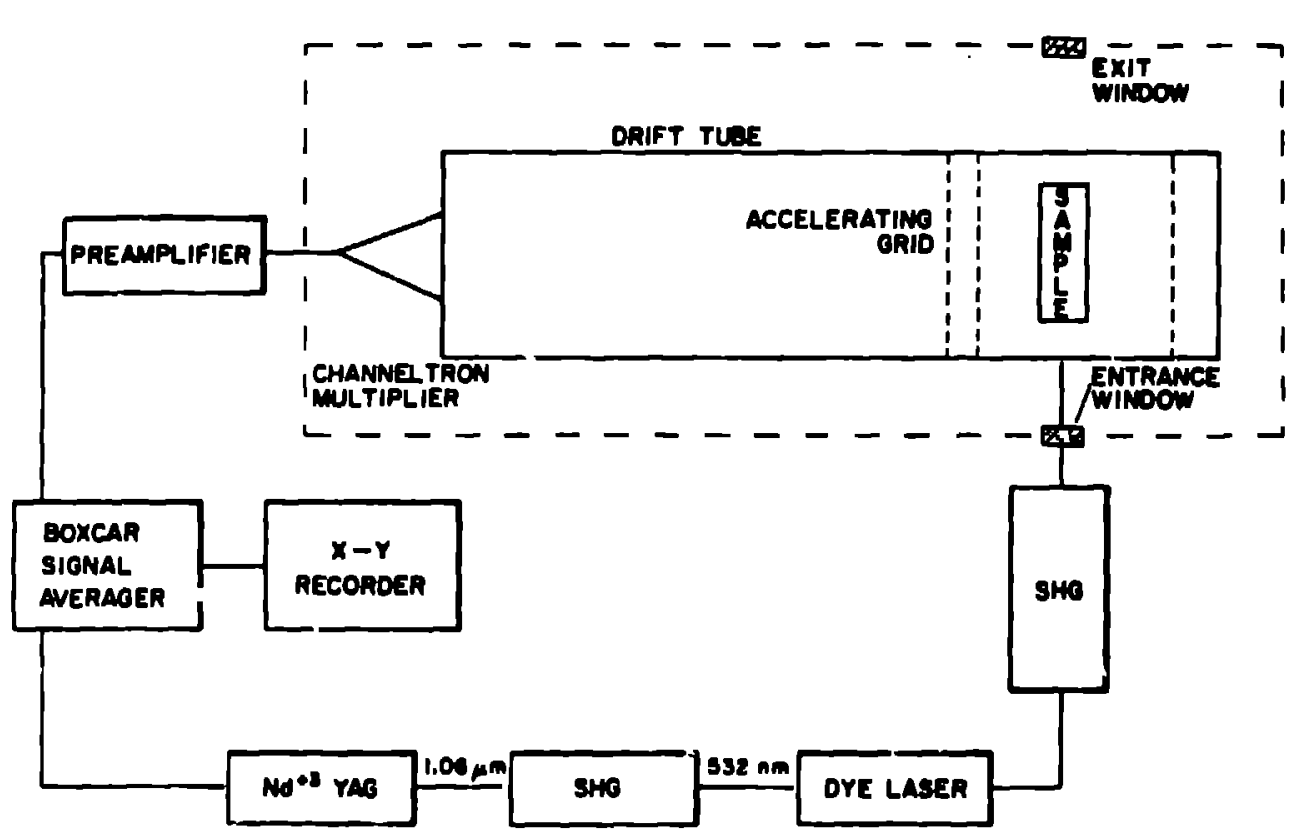

Fig. 1. Schemetlc of experimental apparatue.

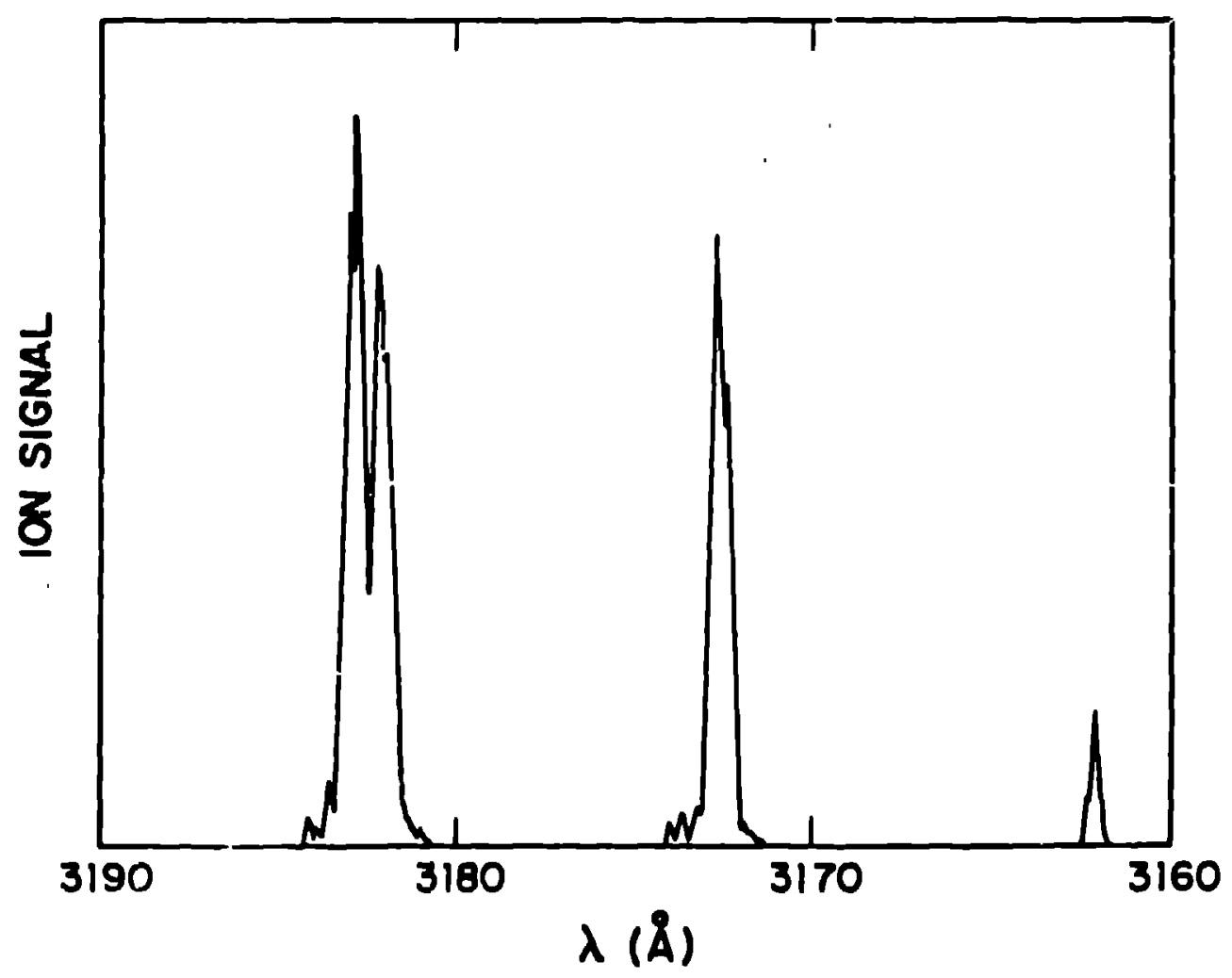

F1g. 2. Wavelength dependence of photolonisation algnal. 


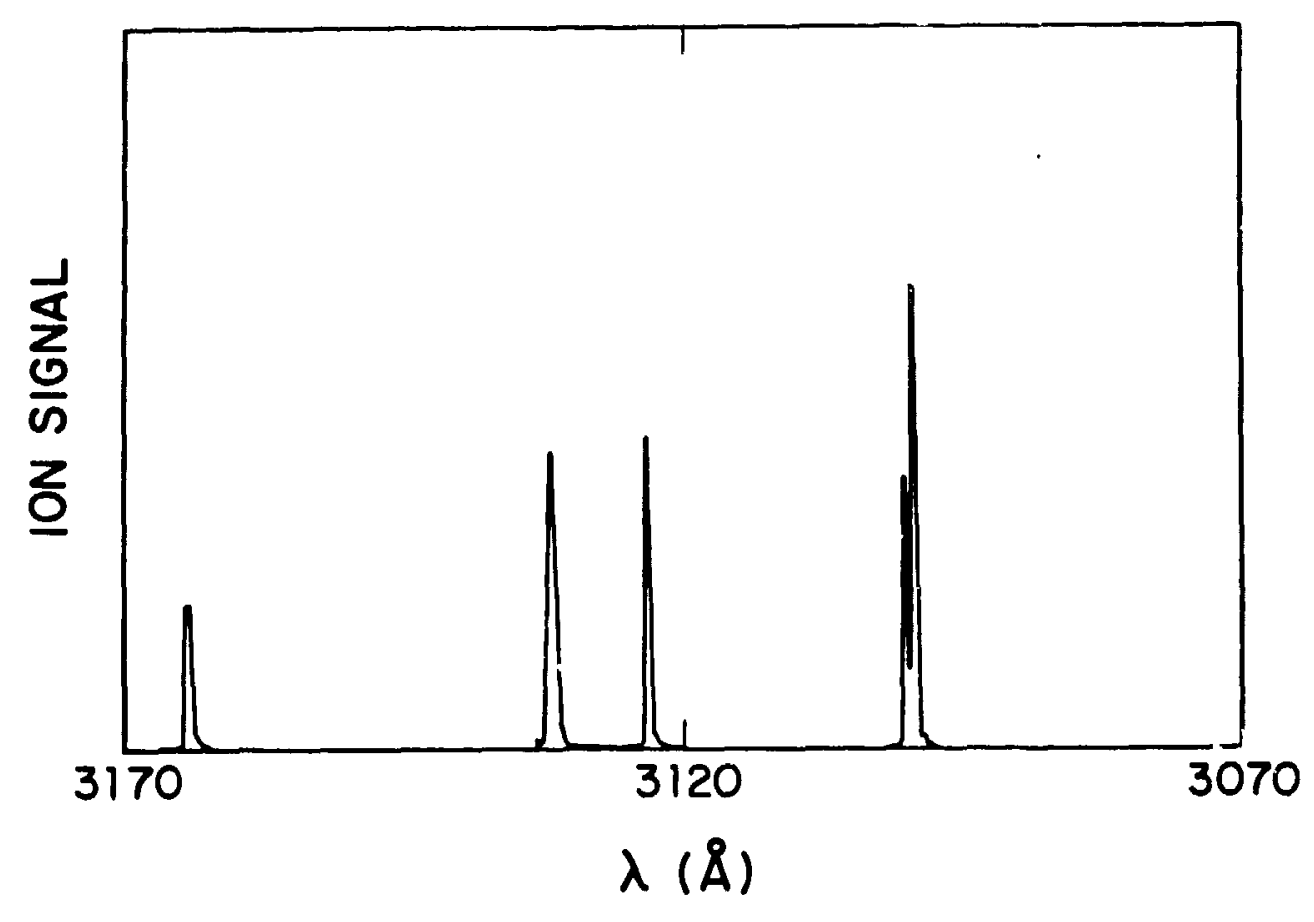

Fig. 3. Wavelength dependence of photoionization signal.

These wavelengthe aro gathered in Table 1, along with tentative assignnents based on published'I TC spectra.

The power dependence of the ion signal at $3183 \mathrm{~A}$ was also examined, and is diaplayed iu Fig. 4. The straight line drawn through the dota lo aisply a linear regression for the data snown, and is not weant to suggest any theoretical justification for a linuar fit. In fact, at very high pulse intensitios, the curve should turn over as the ionization saturates, 19 while at low intensitios, the power dependence shousd be grwater than firat urder. The graph euggeste that the firat transition is eaturated, while the excited atate to continuum transition. is not saturater. However, over the range of intensities used in these experiments, the linear caling inow provides convenient meane of normalizing the ion signale to laser power. This method has been ueed to generate tne relative intensities hown in Table 1. These relative intensities ere thus simply the ion eignal divided by the average pulse energy at that wavelength. Al though no determinatinne were made for the last four entries in Table 1 because of difficulties in obtaining table laser output, the results show in Fig. 3 suggest that at least the 3099 and 3098 A lines way be mualytically useful.

The analytical problem for the detection of solar noutrinos is defined as follows:"14 the accurate determination of the technetium lootope ratio for a caple which contains $220^{\circ}$

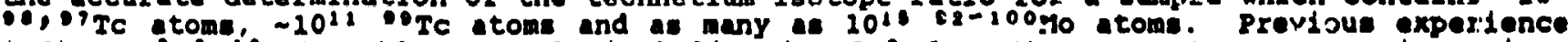

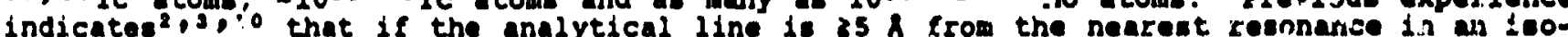
beric interference that diecrimination aginat the interference is complete $\left(810^{\circ}\right)^{\circ}{ }^{\circ}$ since there are a number of TC analyeie ilres to choose fron, and only a handful of lnterfering Mo resonances, the Mo intarference is unlikely to pose a oimifisant prokien [Tulile i]. F'rther, eince these experimente will eventually be conducted on a negnetic anse epectrisn-

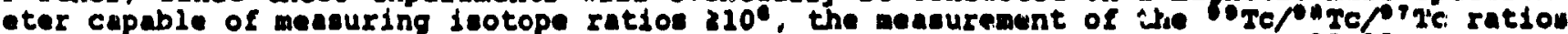

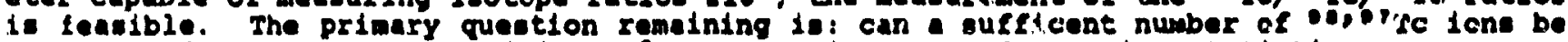
yenerated from a cample containing $10^{\circ}$ atome to inure good counting atatietice.

Firet of all. we will assume that lon production can bo eaturatud over a beam diameter of $0.5 \mathrm{~cm}$. This may be possible for a number of the trensitione $110 t e d$ in Table 1 if If wo aseume that the $1500^{\circ} \mathrm{C}$ TC atoms are moving at a velocity of $4 \times 20^{4} \mathrm{~cm} / \mathrm{s}$, thay will eraversel the beam diameter in $-10^{-1}$. Thue the population of atone in the laser volume will be renewed $10^{\circ} \mathrm{m}^{-1}$. Since the leser operates at $20 \mathrm{Hs}$, the effective duty cycle will be 


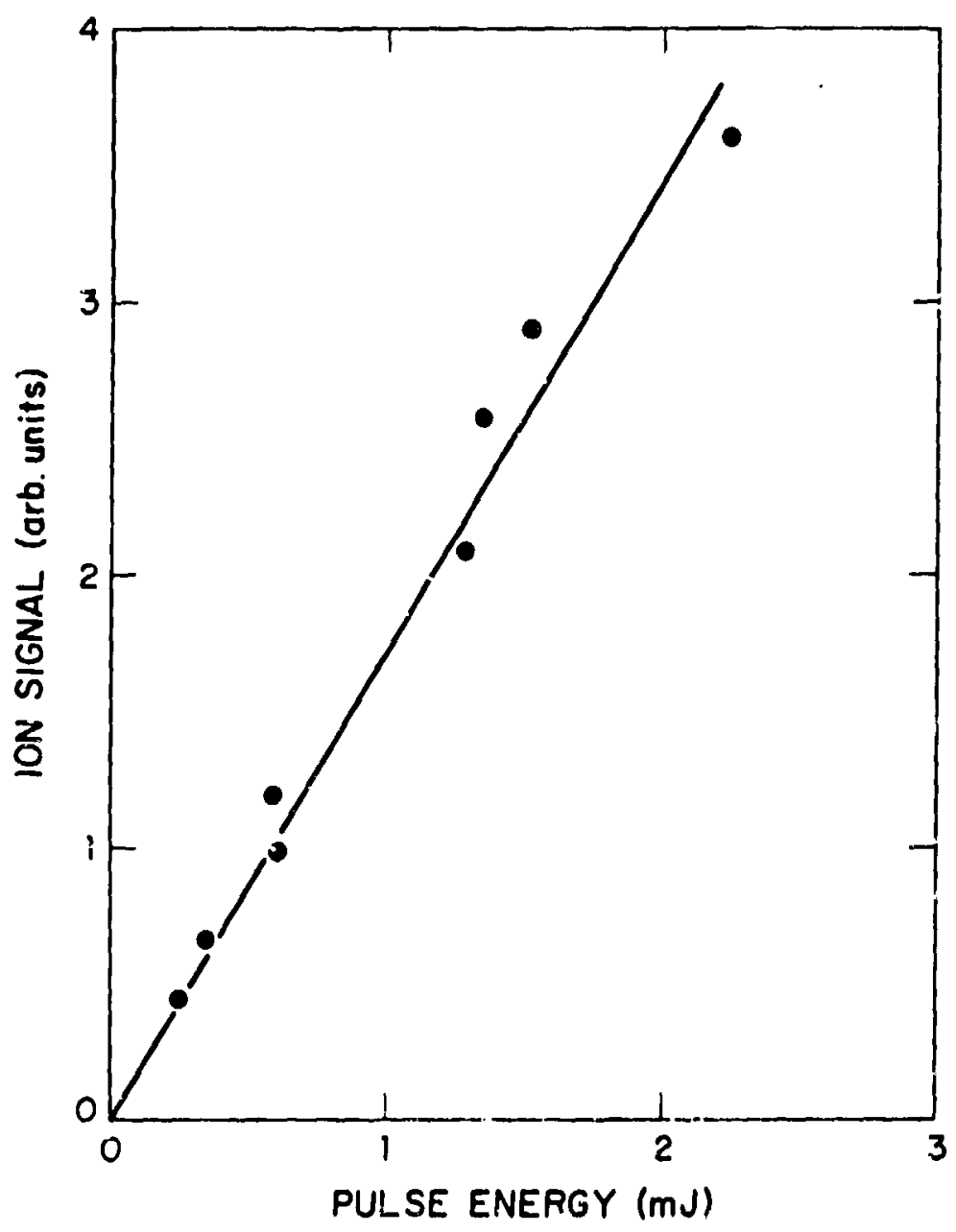

Fig. 4. L.ew energy power dependence of the photolonization signal

10-4. Previous experience indicates that geometris faccora, ion collection and tranamission, and counting inefficiencies will reduce the potential ion signal by 100. Thus. a $10^{\circ}$ tom ample will be expected to produce $\sim 10^{\circ}\left(10^{-4}\right)\left(10^{-2}\right)=10^{2}$ ion counts if atomiza. tion is $100 \%$ efficient. Since the detection of 100 ions is oul, marginally Bulficient to ensure adequate counting statistics, alternatives should be explored.

At least three alternatives suggest themselveb A higher repeticion rate laser might be used. There exist coincidences between the output of a KrF laser and a weak TC line at $\lambda=2484.6 \mathrm{~A}$ transition, and between the Raman-shifted output (secolld Stokes, $H_{3}$ ) of a $K_{L} F$ laser and a trong TC trangition at $\lambda=3123 \mathrm{~A}$. The former of tiese appeara to de free of molybdenum interfezences. Sincs excimer lasers are nox commercially available with repeti. tion rates $>10 \mathrm{~Hz}$, and will soon be available up to $10^{3} \mathrm{~Hz}$, there is the poseibility of gaining $10^{2}$ in the efficiency of ion production amply by changing photon eourcas. This possibility will be investigated in the near future. The use of cw lasers for RIMs has also been suggested, is and recently demonstrated. jon p:oduction using cw laser excitation was > lo that observad using puleef lasers. The generation of subatantial qunntitien of uv light with cw lasers 1 stili a difficult problem, however, 18,17 The most reasonable application of $\mathrm{CW}$ lasess to the Tc problem would lie ir. three-photon, two-color, double-resonance cheme, presumably using the $4238.2 \mathrm{~A}$ resonance for the first step. We are currently exploring this possibility. 
Table 1. Observed Tc Resonance Photoionization Transitions and Pctential Molybdenum

\begin{tabular}{|c|c|c|c|c|}
\hline Observed $\lambda(\lambda)$ & Assignment ${ }^{a}$ & I (Relative) & Mo & Lines \\
\hline 3183 & & 2.5 & 3194 & $\mathbf{S}$ \\
\hline 3182 & & 1.8 & & \\
\hline 3173 & & 3.0 & 3170 & $\mathbf{S}$ \\
\hline 3163 & & 0.8 & 3158 & $\mathbf{S}$ \\
\hline 3131 & & 1.6 & 3132 & $\mathbf{S}$ \\
\hline 3123 & & 2.0 & 3112 & $\mathbf{M}$ \\
\hline 3099 & & $N^{C}$ & & \\
\hline 3098 & & ND & & \\
\hline 3064 & & ND & & \\
\hline 3021 & $2^{4}$ & $\mathbf{N D}$ & & \\
\hline
\end{tabular}

All observed transitions originated in the grouno state $\left(4 d^{8} 58^{2}{ }^{6} S_{5} / 2\right)$ the final state configuxation in all cases $48 \mathrm{~d}^{\circ}\left(\mathrm{a}^{8} \mathrm{D}\right) 5 \mathrm{p}$; assignment indicates the designation of the final level.

b The listed lines are those originating in ground state Mo that lie close to a Tc transition: S-strung, M-medium. From Ref. 12 .

No determination.

Lastly, more clever utilization of the sample may well provide the most dramatic improvement, as well as the mostly generally useful. Methods which utilize either pulsed sample volatilization, 8,10 or trapping of a continucuely volatilized sample could easily increase the effective duty cycle for pulsed lasers by several orders of magnitude. In iddition, trapping schemes may aseist greatly in reducing sample loss from the optical field of view (geometric lose). These problems deserve cerious consideration if RIMs is to bocome a practical analytical tool.

\section{References}

1. C. A. MCDowell, Mase Spectrom-try, NeGraw-Hi1l, San Franc1sco, 1953.

2. C. M. Miller, N. S. Nogar, A. J. Gancarz and W. R. Shields, Anal. Chem. 54, 2377 $(1982)$.

3. C. M. Miller and $N$. S. Negar, Aral. Chem, submitted.

4. J. D. Fassett, J. C. Travis, L. J. Moore and F, E. Lytle, Anal. Chem., lu press.

5. D. L. Donubue, J. P. Young and D. B. Smith, Int. J. Mege Spec. Ion Phre. 43.293

6. D. L. Donahue and J. P. Young, Anel. Chem. 55, 378 (1983).

7. J. P. roung and D. L. Donahue, Anal, Chem. 55, 81 (2982).

197 ; 6. S. Hurst, M. G. Payne, S. D. Kramer and J. P. Young, Rev. Mod. Phye. 51. 767

9. G. A. Cowan and W. C. Haxtori, Science 216, 51 (1982).

10. C. M. Miller, J. B. Cross and N. S. Nogar, Opt. Comm. 40, 271 (1982).

11 . W. R. Bozman, C. R. Corlise and J. L. Tech, J. ReE. Nat. Bur. Stand. I2A, 559 $(1968)$.

12. W. F. Meggerz, C. H. Coriles and B. F. Scribner, Tables of spectral Line Inteneities, NAS $32 / 1$

1.7. We have observed saturation effecte ueing focused beam ( C.3 cm diameter) or high pulse energien, $22 \mathrm{~mJ}$.

14. Private diecussions with G. Cowan, Los Alamos National Laboratory.

15. C. M. Miller and N. 8 . Nogar, Anel. Chem. 55, 481 (2983).

16. C. R. Webster, L. Wbete and $R$. N. 2are, gpt. Conmun. 35,435 (1980).

17. B. Coutliand, Ph. Dabkiewicz, L. A. Bloomileld and T. W. Hinsch, opt. Commun. 35 $359(1980)$

18. S. Mafo, T. B, Lucaturto and G. G. Zuther, Anel. Chen. 54,553 (1982).

19. D. J. Beckman, T. A. Callcott, s. D. Kranes, E. T, Arakawa end C. S. Huret, Int. J. Masa SEectrosc. Ion Phys. 34, 89 (1980).

20. $\tilde{p}$ ivate diacuesione with W. Shielde, Los Alamor National Laboratory. 